\title{
ГЕНДЕРНІ ВІДМІННОСТІ САМОСПРИЙНЯТТЯ В ПІДЛІТКОВОМУ ВІЩІ
}

\begin{abstract}
Представлено результати аналізу гендерних відмінностей самосприйняття в підлітковому віці. Підкреслено актуальність такого дослідження, оскільки неадекватне, спрощене або викривлене самосприйняття призводить до дисгармонійного розвитку особистості в цілому, заважає процесу іiі самореалізації та становленню в соціумі. Визначено роль самосприйняття в процесі побудови Я-образу і Я-концепції, виявлено його вплив на змістове наповнення уявлень, що забезпечують специфіку самоусвідомлення особистості. Емпірично доведено, що на самосприйняття особистості в підлітковому віці значною мірою впливають гендерні стереотипи, згідно з якими чоловіки повинні мати такі якості, як активність, сила, самостійність, агресивність, демонстративність, наполегливість, прагнення до домінування, незалежності й досягнень, а жінки - схильність до концентрації на почуттях, експресивність, дружелюбність, чулість, слабкість, покірність, турботливість.

Ключові слова: самосприйняття, Я-образ, Я-концепція, самосвідомість, гендер.
\end{abstract}

Постановка проблеми. Виявлення психологічних особливостей сприйняття особистістю себе $є$ актуальним завданням, що постає сьогодні перед науковцями і практиками, оскільки саме від специфіки самосприйняття залежить зміст Я-образу, Я-концепції та самосвідомості людини. Неадекватне, спрощене або викривлене самосприйняття призводить до дисгармонійного розвитку особистості в цілому, заважає процесу їі самореалізації та становленню в соціумі.

Аналіз останніх досліджень і публікацій, виокремлення невирішених частин загальної проблеми. У сучасній науці наразі існують різні підходи до аналізу феномену самосприйняття. Так, на думку О. Г. Спіркіна, самосприйняття пов'язане зі здатністю до самопізнання, що розглядається як виключний здобуток людини, яка усвідомлює саму себе як суб'єкта свідомості, спілкування і дій. Дослідник вважає, що тільки в цій формі і може існувати самосвідомість. Ї̈̈ основна особливість у тому, що вона спрямована на осмислення людиною своїх вчинків, почуттів, думок, мотивів поведінки, інтересів, свого становища в суспільстві. Самосвідомість - це іiі знання про саму себе. Завдяки самосві-домості людина сприймає себе як індивідуальну реальність, відокремлену від природи та інших людей. Таким чином вона існує не тільки для інших, а й для себе [5, с. 141].

I. I. Чеснокова стверджує, що самосвідомість являє собою єдність трьох аспектів: пізнавального (самосприйняття), емоційно-ціннісного (самоставлення) і дієвовольового, або регулятивного (саморегуляція). 
На іiі думку, з позицій психологічного аналізу самосвідомість - це складний психічний процес, суть якого у сприйнятті особистістю багатьох “образів” себе в різних ситуаціях діяльності й поведінки, у всіх формах взаємодії з іншими людьми та в поєднанні цих образів у єдине цілісне утворення - в уявлення, а потім - у поняття свого власного "Я" як суб'єкта, що відрізняється від інших суб'єктів. У результаті розгортання актів самосвідомості, яка все більше ускладнюється, у міру збільшення кількості образів, що інтегруються в уявлення і поняття про самого себе, формується все більш бездоганний, глибокий і адекватний образ власного "Я" [7, с. 29-30].

На думку I. С. Кона, самосприйняття лежить в основі уявлень особистості про себе, а отже, забезпечує функціонування самосвідомості. Він виділяе в структурі самосвідомості чотири компоненти, пов'язані з усвідомленням своєї тотожності, власного “Я”, своїх психічних властивостей і певною системою соціально-моральних самооцінок [3, c. 232-240].

Результатом процесу самосприймання $є$ формування Я-концепції. Р. Бернс виділяє когнітивну, афективну та поведінкову складові Я-концепції. Когнітивна складова - це уявлення індивіда про самого себе. Як правило, вони здаються йому переконливими незалежно від того, чи грунтуються вони на об'єктивному знанні або суб'єктивній думці, чи $є$ вони істинними або хибними. Афективна складова настановлення існує тому, що його когнітивна складова не сприймається людиною байдуже, а викликає в неї оцінки та емоції, інтенсивність яких залежить від контексту і самого когнітивного змісту [1, с. 30-39].

Досить цікаво, на наш погляд, Р. Бернс трактує Я-концепцію - у вигляді ієрархічної структури. Ї̈̈ вершину увінчує глобальна Я-концепція, що охоплює різні межі індивідуальної самосвідомості. Образ “Я” і самооцінка мають лише умовні концептуальні відмінності, оскільки в психологічному плані вони нерозривно взаємопов'язані. Образ і оцінка свого "Я" спонукають індивіда до певної поведінки, тому глобальну Я-концепцію можна розглядати як сукупність настановлень індивіда, спрямованих на самого себе [там само, с. 61]. Це твердження поглиблює I. І. Чеснокова, яка стверджує, що в Я-концепції міститься оцінка особистістю самої себе і більш або менш адекватно відображається рівень іiі власної гідності. Залежно від останнього людина може переживати почуття своєї неповноцінності або ж, навпаки, почуття своєї невиправданої переваги над іншими [7, с. 87].

Наслідком процесу самосприймання $є$ виникнення позитивного або негативного самоставлення особистості. О. О. Маслова порушує питання про узгодженість окремих самооцінок та їх об'єднання в загальне почуття позитиву або негативу індивіда щодо себе. Вона виділяє п’ять основних підходів до розуміння глобальної самооцінки (загальної 
самоповаги, самоставлення) та ії структури: 1) самоставлення як сума часткових самооцінок, пов'язаних із різними аспектами Я-концепції; 2) самоставлення як ієрархічна структура, що охоплює часткові самооцінки, інтегровані за сферами особистісних проявів; разом вони становлять узагальнене "Я", яке перебуває на вершині ієрархії; 3) самоповага - самостійна змінна, що має свою особливу природу; 4) самоставлення як почуття, що виявляється у переживанні різного змісту (самовпевненість, самоприйняття); 5) самоприйняття як прийняття себе в цілому, незалежно від своїх якостей і переваг [4].

Емоційне ставлення до людини - іншої або самої себе - має свою специфіку. І. С. Кон розглядає поняття “самоповага", визначаючи його як підсумковий вимір “Я”, що виражає міру прийняття або неприйняття індивідуумом самого себе, позитивне або негативне ставлення до себе, що $є$ похідною від сукупності окремих самооцінок [2].

В. В. Столін на основі поглибленого аналізу праць попередників тлумачить емоційно-ціннісне ставлення особистості до себе як результат й інтегратор механізмів особистісної самосвідомості, що має складну психологічну структуру. Як почуття, воно характеризується розміреністю, включаючи осі симпатії, поваги і близькості. Феноменальне ставлення до себе проявляється у вигляді внутрішнього діалогу між “Я” і “не-Я”, схожим і відмінним від самого суб'єкта, регулює усвідомлене або неусвідомлене емоційно-ціннісне ставлення до себе, яке переживається [6, с. 121-123].

Попри чималий доробок в означеній галузі психологічного знання недостатньо дослідженими залишаються, однак, психологічні особливості самосприйняття в підлітковому віці, що й зумовило мету роботи виявити гендерні відмінності самосприйняття підлітків.

Виклад основного матеріалу дослідження. В емпіричному дослідженні особливостей самосприйняття в підлітковому віці, що проводилося протягом 2017 р., взяли участь 80 учнів 8-х класів ЗОШ №12 м. Рівного.

У ході дослідження було використано методику особистісного диференціала Ч. Осгуда (табл. 1). Шкала “оцінка” відображає, які якості - позитивні або негативні бачить у собі особистість, як вона оцінює свої психологічні особливості та риси характеру. Шкала “сила" показує, як підлітки усвідомлюють свої вольові характеристики та здатність до саморегуляції. Шкала “активність” дає змогу виявити енергетичний потенціал особистості, іiі дієвість та працездатність. На основі сукупності цих характеристик можна оцінити особистість у цілому та виявити, як вона усвідомлює власні психологічні особливості, яке в неї переважає сприйняття себе - позитивне або негативне. 
Таблиия 1

Показники самосприйняття (за результатами особистісного диференціала Ч. Осгуда)

\begin{tabular}{|c|c|c|c|}
\hline \multirow{2}{*}{ Показники } & \multicolumn{3}{|c|}{ Шкали } \\
\cline { 2 - 4 } & “Оцінка" & “Сила" & "Активність” \\
\hline $\bar{X}$ по групі & 32,9 & 30,1 & 37 \\
\hline $\bar{X}$ дівчат & 27,5 & 28,8 & 43,7 \\
\hline $\bar{X}$ хлопців & 38,3 & 31,5 & 30,2 \\
\hline
\end{tabular}

У процесі дослідження було визначено також показники респондентів за шкалами “оцінка”, “сила” та “активність” (рис.).

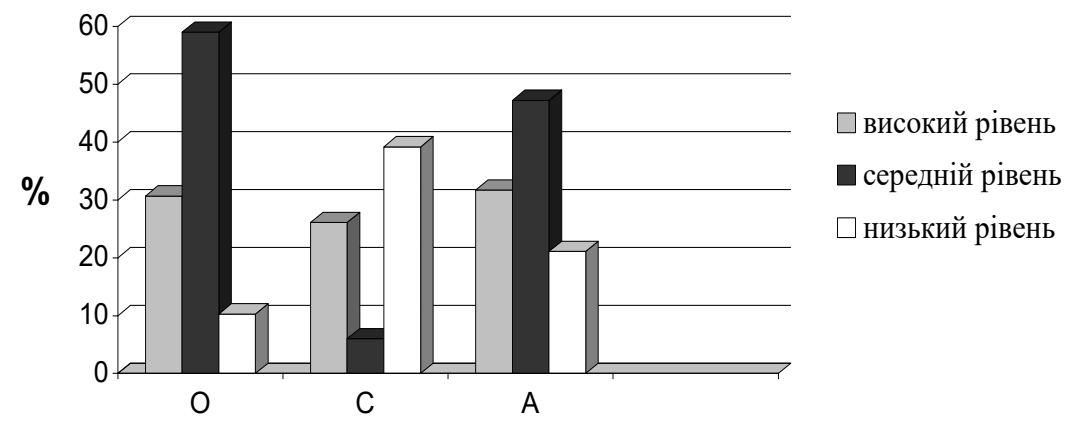

Примітка: О - шкала “оцінка”; С - шкала “сила”; А - шкала “активність”.

Рис. Рівні “оцінки”, “сили”, “активності” (за результатами особистісного диференціала Ч. Осгуда) (у \%)

Високий рівень за шкалою “оцінка” виявлено у досліджуваних, яким властиві самоповага, прийняття себе як особистості, усвідомлення себе як носія позитивних, соціально схвалюваних характеристик. У цих підлітків здебільшого позитивне емоційно-ціннісне ставлення до себе та високий рівень самоприйняття. В окремих випадках спостерігається некритичне ставлення до себе: такі підлітки не здатні виділити, усвідомити свої недоліки. Через завищену самооцінку у них часто складається неадекватне уявлення про себе, вони схильні перебільшувати свої можливості, переоцінювати власні сили. Неадекватне уявлення про себе нерідко стає причиною вибору дітьми хибних шляхів до самоствердження, непомірних домагань.

Подальший аналіз результатів показав, що діагностовані, яким притаманний середній рівень за шкалою “оцінка", у цілому позитивно ставляться до власного “Я”, усвідомлюючи при цьому власні недоліки. Це свідчить про адекватну самооцінку, що випливає з факту сформова- 
ної самосвідомості та достатнього розвитку рефлексії. Такі підлітки виявляють позитивне емоційно-ціннісне ставлення до себе.

Серед респондентів було виявлено також осіб, які мають низький рівень за шкалою “оцінка". Тобто в цій групі є особи з негативним самоставленням, низьким рівнем самоповаги та заниженою самооцінкою. Такі підлітки не усвідомлюють себе як носіїв соціально бажаних характеристик і бачать себе здебільшого в негативних барвах. Вони найчастіше невдоволені власною поведінкою, рівнем своїх досягнень, особливостями свого характеру.

Підлітки, які мають високі показники за шкалою “сила”, вважають, що в них досить розвинута воля, що вони рішучі, здатні, незважаючи на перешкоди, цілеспрямовано йти до поставленої мети, долати труднощі, які виникають у їхньому житті. Вони вважають себе незалежними і переконані, що в складних ситуаціях слід розраховувати тільки на власні сили. В окремих випадках це може свідчити про завищену самооцінку та схильність переоцінювати свої можливості.

Респонденти, у яких середній рівень за цією шкалою (тобто які помірно впевнені в собі), мають здебільшого адекватну самооцінку. Такий підліток усвідомлює себе як відносно незалежну й рішучу людину, яка прагне досягти своєї мети.

Підлітки з низьким рівнем за шкалою “сила" виділяють у собі такі якості, як слабкість, нерішучість, надмірна поступливість, залежність від оточення, невпевненість у собі. Для них характерна занижена самооцінка, з якої випливає неприйняття себе, низький рівень самоповаги, схильність перебільшувати свої недоліки та акцентувати увагу на слабких сторонах власної особистості.

Підлітки, які мають високі показники за шкалою “активність”, усвідомлюють себе як енергійних, високопрацездатних людей. Цей показник інтерпретується як екстравертованість особистості, тобто як прагнення до контактів, відкритість, комунікабельність, висока мовленнєва активність. Ці респонденти вважають себе товариськими, легко налагоджують контакти із широким колом людей, заводять нові знайомства тощо.

Середній рівень за цією шкалою мають досліджувані, які сприймають себе як людей помірно активних і діяльних, помірно комунікабельних. Вони тримаються зазвичай центру між полюсами екстраверсії та інтроверсії і, залежно від обставин, зміщуються до одного 3 них.

Для підлітків із низьким рівнем за шкалою “активність” характерні замкнутість і пасивність. Такі люди спокійні, стримані, мовчазні, не прагнуть до великої кількості контактів, обмежуються спілкуванням із кількома близькими друзями.

У ході подальшого дослідження було виявлено гендерні відмінності самосприйняття в підлітковому віці (табл. 2). Для перевірки статистичної значущості виявлених змін було використано критерій 
$\chi^{2}$-Пірсона. За шкалою “оцінка" значення $\chi^{2}=6,53\left(\chi_{\text {кр }}^{2}=5,99, \mathrm{p}<0,05\right)$, тобто незначною мірою перевищує критичне, що свідчить про наявність певних гендерних відмінностей.

Табличя 2

Гендерні відмінності самосприйняття (\%)

\begin{tabular}{|l|c|c|c|c|c|c|}
\hline \multirow{2}{*}{ Шкали } & \multicolumn{7}{|c|}{ Рівні } \\
\cline { 2 - 7 } & \multicolumn{2}{|c|}{ високий } & \multicolumn{2}{c|}{ середній } & \multicolumn{2}{c|}{ низький } \\
\cline { 2 - 7 } & д & $\mathbf{x}$ & д & $\mathbf{x}$ & д & $\mathbf{x}$ \\
\hline “Оцінка" & 26,2 & 35,6 & 60,0 & 57,0 & 13,8 & 7,4 \\
\hline “Сила” & 17,0 & 35,4 & 32,3 & 35,4 & 50,7 & 29,2 \\
\hline “Активність” & 27,7 & 35,4 & 55,3 & 38,4 & 17,0 & 26,2 \\
\hline
\end{tabular}

Примітка: $\mathrm{x}$ - хлопці, д - дівчата.

Порівнюючи отримані результати, бачимо, що високий рівень за цією шкалою мають здебільшого хлопці. Тобто хлопці дають собі високі оцінки вираженості якостей, які в суспільстві визнаються бажаними. Вони виділяють у власній особистості багато позитивних характеристик, які часто є об'єктивно не підтвердженими, що свідчить про тенденцію до завищення самооцінки та про ії недостатню адекватність. Натомість самооцінки дівчат здебільшого реалістичні та в основному адекватні. Дівчата оцінюють власні особистісні риси та якості не так високо, як хлопці. Це можна пояснити тим, що згідно з гендерними стереотипами хлопцям приписуються такі соціально бажані риси, як незалежність, рішучість, самостійність, упевненість. Хлопці прагнуть відповідати гендерним очікуванням та характеризують себе як осіб, у яких ці риси яскраво проявляються. Натомість від дівчат суспільство не очікує яскравого вияву цих якостей, і вони, прагнучи відповідати стереотипним уявленням, на свідомому, або й підсвідомому, рівні характеризують власну особистість як таку, якій названі риси притаманні меншою мірою (хоча інколи це не відповідає дійсності, а такі самохарактеристики виділяються для того, щоб відповідати гендерним очікуванням i, таким чином, не викликати осуд та негативну оцінку оточення).

Як серед дівчат, так і серед хлопців виявлено досить значну кількість осіб із середнім рівнем за шкалою “оцінка", але показник хлопців дещо вищий. Це свідчить про те, що респонденти виділяють у собі як позитивні, так і негативні риси. У цій групі досліджуваних не спостерігається схильність до ідеалізації власного “Я”, однак вони не схильні перебільшувати свої недоліки. Низький рівень за шкалою "оцінка" мають більше дівчат, аніж хлопців. Звідси випливає, що дівчата здебільшого схильні перебільшувати свої недоліки, мають низький рівень самоповаги, низький ступінь самоприйняття. Вони більш чутливі до негативних впливів з боку оточення, їхня самооцінка дещо нестійка. 
Відтак визначалася значущість гендерних відмінностей за шкалою “сила". У досліджуваній групі $\chi^{2}=31,39$, тобто цей показник значно перевищує критичне значення $\left(\chi^{2}\right.$ кр $\left.=5,99, \mathrm{p}<0,05\right)$. Високий рівень за цією шкалою мають більше хлопців, ніж дівчат. Це свідчить про те, що хлопці більшою мірою схильні виділяти в собі такі якості, як рішучість, сила волі, наполегливість, упевненість, незалежність, схильність розраховувати лише на свої сили. Низький рівень за цією шкалою переважає в дівчат. Для них характерні такі риси, як слабкість, залежність, нерішучість, пасивність, поступливість та невпевненість. Це пов'язано з прагненням дівчат проявляти фемінінні риси, що є ознакою жіночності, до якої, відповідно до гендерних експектацій, має прагнути кожна дівчина та жінка. Фемінінність передбачає наявність таких рис, як схильність до підпорядкування, слабкість та пасивність. I хоча в сучасному суспільстві відбувається зміна уявлень про риси, які повинні бути притаманні жінці, у напрямі збільшення ії маскулінності або андрогінності (що пов'язано зі змінами соціально-економічного устрою нашої країни), значна частина дівчат підліткового віку характеризує себе як високофемінінних.

Що ж до значущості відмінностей у вираженості ознаки “активність”, то за цим показником значення $\chi^{2}=12,37$, тобто перевищує критичне $\left(\chi_{\text {кр }}^{2}=5,99, \mathrm{p}<0,05\right)$. Для хлопців більшою мірою характерні такі особливості, як високий рівень працездатності, енергійність, у деяких випадках - дратівливість. Вони вважають себе активними, здатними легко долати труднощі.

Висновки. Аналізуючи отримані результати, можна стверджувати, що на самосприйняття особистості підліткового віку значною мірою впливають гендерні стереотипи, згідно з якими чоловіки повинні мати такі якості, як активність, сила, самостійність, потреба в домінуванні, незалежності й досягненнях, агресивність, демонстративність, наполегливість. Прагнення відповідати зразкам маскулінності призводить до перебільшення власних сил, активності та домінантності. Натомість до дівчат суспільство висуває не такі жорсткі вимоги, оскільки гендерні стереотипи жіночності полягають у наявності таких рис, як схильність до концентрації на почуттях, експресивність, дружелюбність, чулість, слабкість, покірність, турботливість.

Перспективним напрямом дослідження є розроблення психологічних засобів, спрямованих на оптимізацію процесу самосприйняття в підлітковому віці.

\section{Лimepamypa}

1. Бернс Р. Развитие Я-концепции и воспитания : [пер. с англ.] / Р. Бернс. Москва : Прогресс, 1996. - 421 с.

2. Кон И. С. В поисках себя: личность и ее самосознание / И. С. Кон. Москва : Политиздат, 1984. - 211 с. 
3. Кон И. С. Открытие “Я”/ И. С. Кон. - Москва : Политиздат, 1998. - 367 с.

4. Маслова Е. А. Психологическая природа самооценки, место самооценки в структуре самосознания личности / Е. А. Маслова // Вестник МПГУ. 2004. - № 15. - С. 24-28.

5. Спиркин А. Г. Сознание и самосознание / А.Г. Спиркин. - Москва : Политиздат, 1992. - 303 с.

6. Столин В. В. Самосознание личности / В. В. Столин. - Москва: МГУ, 1993. - $284 \mathrm{c}$.

7. Чеснокова И. И. Проблема сознания в психологии / И. И. Чеснокова. Москва : Наука, 1997. - 144 с.

\section{References}

1. Berns, R. (1996). Razvitiye Ya-kontseptsii i vospitaniya [Development of selfconcept and education]. Moscow: Progress Publ. (rus).

2. Kon, I. S. (1984). V poiskakh sebya: lichnost i yeye samosoznaniye [In Search of Yourself: Personality and Self-Consciousness]. Moscow: Politizdat Publ. (rus).

3. Kon, I. S. (1998). Otkrytiye "Ya" [The discovery of "I"]. Moscow: Politizdat Publ. (rus).

4. Maslova, Ye. A. (2004). Psikhologicheskaya priroda samootsenki, mesto samootsenki v strukture samosoznaniya lichnosti [The psychological nature of self-esteem, the place of self-esteem in the structure of a person's selfawareness]. Vestnik MPGU [MSGP Bulletin], 15, 24-28 (rus).

5. Spirkin, A. G. (1992). Soznaniye i samosoznaniye [Consciousness and selfawareness]. Moscow: Politizdat Publ. (rus).

6. Stolin, V. V. (1993). Samosoznaniye lichnosti [Self-awareness of personality]. Moscow (rus).

7. Chesnokova, I. I. (1997). Problema soznaniya v psikhologii [The problem of consciousness in psychologists]. Moscow: Nauka Publ. (rus).

\section{Kaminska O. V. Gender Differences of Self-Perception of Teenagers}

The results of the analysis of gender differences in self-perception in adolescence are presented. This study is important because inadequate, oversimplified or distorted self-image leads to disharmony of the whole person, hinders the process of selfformation and in society. The role of independence in the process of self-image and the self-concept constructing has been determined, its influence on the content filling of representations ensuring the specificity of the self-awareness of the individual has been identified. It has been empirically proven that gender self-perception in adolescence is largely influenced by gender stereotypes, according to which men must have the qualities such as activity, strength, autonomy, aggressiveness, demonstrability, persistence, desire for dominance, independence and achievement, and women are predisposed to concentration on feelings, expressiveness, friendliness, chastity, weakness, obedience, caring.

Key words: self-perception, self-image, self-concept, self-consciousness, gender.

(C) Камінська О. В. 